\title{
Universiteit
}

Leiden

The Netherlands

\section{Alliances, signals of support, and military effort} DiGiuseppe, M.R.; Shea, P.E.

\section{Citation}

DiGiuseppe, M. R., \& Shea, P. E. (2021). Alliances, signals of support, and military effort. Eur J Int Relat, 27(4), 1067-1089.

doi:10.1177/13540661211033890

Version: $\quad$ Publisher's Version

License: $\quad$ Creative Commons CC BY 4.0 license

Downloaded from: https://hdl.handle.net/1887/3249699

Note: To cite this publication please use the final published version (if applicable). 


\section{Alliances, signals of support, and military effort}

\author{
Matthew DiGiuseppe (iD
}

Leiden University, Netherlands

\section{Patrick E. Shea}

University of Houston, USA

\author{
European Journal of \\ International Relations \\ 202I, Vol. 27(4) 1067-1089 \\ (C) The Author(s) 2021 \\ (c) (i) \\ Article reuse guidelines: \\ sagepub.com/journals-permissions \\ DOI: 10.1 I 177/I354066/21/1033890 \\ journals.sagepub.com/home/ejt
} ๑SAGE

\begin{abstract}
Do alliances allow states to share defense burdens and reduce military spending? Despite expectations that alliances should lead to decreased military spending, the empirical record offers mixed findings. We argue that not all alliances are reliable; thus, only allies that receive signals of reassurance will rely on the external security of allies and subsequently reduce their military spending. Compared to states that do not receive additional signals, these reassured allies will have greater confidence that an ally will come to their aid. As a result, third-party aggressors are deterred and the demand for military spending will decrease. We test this argument with an analysis of US signals of support, alliance commitments, and military spending. We find that American alliances without additional signals of support have a negligible effect on military spending. Yet, we observe that alliances are negatively associated with military spending when signals of support are present. Additional tests indicate that alliance commitments, coupled with strong US signals, are also associated with lower military spending in the rivals of US allies. Our results potentially help explain the mixed evidence in the arms-versus-allies and burden-sharing literatures and further demonstrate that extra-alliance signals play an important role in the practice of International Relations.
\end{abstract}

\title{
Keywords
}

Alliances, military expenditure, security, foreign policy, burden sharing, quantitative analysis

\section{Corresponding author:}

Matthew DiGiuseppe, Leiden University, P.O. Box 9555, Leiden, South Holland 2300 RA, Netherlands.

Email: m.r.di.giuseppe@fsw.leidenuniv.nl 
In a surprise announcement in June 2018, US President Trump declared an end to joint military exercises with South Korea in an attempt to curb North Korea's nuclear program (Smith and Stewart, 2018). These exercises were originally designed to increase coordination and readiness of US and South Korean forces and act as a way to "reaffirm US commitment to the alliance." While the military exercises were later rescaled, the initial announcement raised concerns about US' commitment to South Korea's security. Shortly after President Trump's decision, South Korea announced it was going to build its own aircraft carrier and increase military spending by $10 \%$ because of the "recent uncertain security environment" (Smith, 2019). A similar situation played out in Europe in June 2020. The Trump administration reduced the number of troops stationed in Germany by $25 \%$ in what was interpreted as retaliation for Germany's "delinquent" contributions to the North Atlantic Treaty Organization (NATO). This has led many in Europe to further question the US' commitment to the security pact. The action led the German defense minister, Annegret KrampKarrenbauer, to remark "it means we Europeans must become able to act more so than is the case today."

Alliances, like NATO or the US-South Korea alliance, are designed to reduce uncertainty between states and to deter adversaries. If sufficiently credible, interstate alliances allow states to share the burden of defense and benefit from economies of scale (Altfeld, 1984; Conybeare, 1992, 1994; Lake, 1999). Subsequently, alliances can help leaders overcome the limitations of fixed budget constraints and allow governments to dedicate more resources toward domestic consumption without sacrificing security (Allen and DiGiuseppe, 2012; Kimball, 2010; Narizny, 2003). Conversely, the absence of credible alliances prompts leaders to divert money from domestic consumption to increase the provision of security. The possibility of forming alliances thus presents a trade-off. Governments can arm externally by allying or they can arm internally by increasing their military spending. This trade-off implies clear observable outcomes; researchers should observe lower military spending in states with alliances relative to those that forgo an alliance. Further, states with lower military effort should be more likely to form alliances (Diehl and Goertz, 2001; Morrow, 2000).

Despite these logical expectations, there is mixed evidence of substitution between alliances and domestic armaments. Some work finds evidence that arms and alliances are substitutes (Allen and DiGiuseppe, 2012; Conybeare, 1992, 1994; Kimball, 2010; Morrow, 1993; Sorokin, 1994), while others find them to be complements (Diehl, 1994; Horowitz et al., 2017; Morgan and Palmer, 2000). Why do we observe this disparity in results? One potential answer is that not all alliances and alliance partners are equal. While defensive pacts may hold similar commitments on paper, the strength of the commitment to intervene is dependent on other factors. If allies cannot trust each other's commitment, they will make themselves vulnerable if they reduce their own military expenditure. As such, the willingness of states to reduce military spending should vary with the credibility of the alliance. The difference in the ability of allies to demonstrate the credibility of their commitment in an anarchic system had been the focus of years of alliance research (Leeds, 2003; Morrow, 1994; Smith, 1995). Scholars have only begun to apply this logic to understanding the arms-versus-allies trade-off. Notably, DiGiuseppe and Poast (2018) argue that because democratic institutions impose greater costs on 
governments for abandoning an ally than autocratic institutions (Mattes, 2012a), we should observe the arms-versus-allies trade-off among states with democratic allies and not among states with non-democratic allies. ${ }^{2}$

Yet, democratic institutions do not help explain why South Korean and European leaders are uncertain about US commitments following the cancellation of joint military exercises, troop withdrawals, and frequent (public and private) statements from President Trump questioning the necessity of the alliance agreements. We do not contest that regime type plays a role in establishing the credibility of an alliance. We argue that beyond regime type, additional costly signals like joint military exercises, troop deployments, and public declarations further increase the credibility of alliances. Scholars have long established the importance of signals in the deterrence literature (e.g. Schelling (1960)). More recent research further demonstrates that a wide variety of actions serve as signals that inform adversaries and allies about the strength of international commitments (Fuhrmann and Sechser, 2014; Malis and Smith, 2021; McManus, 2014, 2018; McManus and Nieman, 2019; McManus and Yarhi-Milo, 2017). We seek to connect research on such signals to alliance dynamics to clarify when states will take advantage of their alliances and reduce military spending and when they will retain or increase their military power through domestic means.

Signals serve two related purposes. First, they help convince allies of the commitment to defend at the heart of an alliance. This is especially important when it is not clear if the original motivation for the alliance persists. Second, because third parties are also an audience to such signals, signals act as a deterrent mechanism and further reduce the demand for military spending. As a result, allies receiving such signals will be more likely to reduce their domestic security outlays. Further, the ally's adversaries should also be deterred from arming if they think intervention is credible. Absent additional signals, we expect that alliances will lead to negligible decreases in military spending.

We test for our argument by focusing on the allies of the US between 1960 and 2010. Our results indicate that a US alliance alone has a trivial impact on the military expenditure of their allies compared to states without an alliance. However, the effect of alliances on military effort strengthens as the US takes additional steps to support its alliance partners. Further, we test an additional implication of our argument. We find that when the US sends stronger signals of support to allies, we also observe that the strategic rivals of US allies have lower military spending than when the US sends fewer signals of support. This further suggests that signals have a deterrent effect in conjunction with alliance commitments.

Our argument and findings have obvious implications for the arms-versus-allies question (Horowitz et al., 2017; Kimball, 2010), but also the closely related literature on burden-sharing (Becker, 2019; Olson and Zeckhauser, 1966; Plumper and Neumayer, 2014). They also hold broader implications for our understanding of formal treaties. We highlight that the formal commitment mechanism of an alliance agreement alone is not sufficient to change the behavior of states when it comes to the provision of their security. Signals also matter. As such, if willingness to reduce military spending is a reliable measure of "alliance quality," our work speaks to decades-long debates regarding the interplay of formal and informal actions in the ability of alliances to deter third-party aggression from external actors (Fearon, 1997; Fuhrmann and Sechser, 2014; Mattes, 
2012b; McManus, 2018; Morrow, 1993, 1994). Our argument also has implications for the literature on military effort. Recent research suggests that domestic factors, like regime type, budget rules, and economic factors, are the primary causes of military expenditure (Becker, 2019; Cappella Zielinski et al., 2017; Fordham, 2002). Our study shows that international cooperation does matter, but a binary alliance indicator fails to capture the effect of external cooperation on military spending.

Our argument also has policy implications. The cases of South Korea and NATO are not in isolation. The presence of US active-duty troops overseas was at its lowest level in decades as the Trump Administration took office (Bialik, 2017). If this trend persists and other signals do not substitute for troops deployments, our analysis suggests an increase in arms spending among both US allies and their adversaries is likely.

\section{Alliance credibility, burden sharing, and costly signals}

Security is expensive and survival-motivated national leaders face pressure to provide not only security but also domestic goods (Kimball, 2010). One way to increase security and domestic goods is to retain a commitment from other states to intervene in times of crisis (Barnett and Levy, 1991; Morgenthau, 1948; Morrow, 1993; Narizny, 2003). Cooperation with other states can reduce the costs of security through achieving economies of scale, gains through specialization in activities, and the coordination of joint forces (Johnson and Leeds, 2011; Lake, 1996). In asymmetric alliances, smaller states have an even greater ability to reduce their military spending. Collective action dynamics suggest that they can "free-ride" on the contributions of larger states, as their contributions matter less to the provision of security for the alliance as a whole (Olson and Zeckhauser, 1966).

Alliances are attractive to survival-minded politicians because they provide security while freeing up domestic resources to provide public or private goods to constituents (Kimball, 2010). Yet, alliances are not costless. Alliances come with the risk of abandonment during a crisis and the risk of entrapment as allies may become emboldened to start an unwanted war. Further, smaller states in asymmetric alliances must often make policy concessions to the larger state (Morrow, 1991). Given such costs, states may opt to provide their own security. As a result, a clear trade-off presents itself. Governments that forgo alliances have a strong incentive to arm internally and will likely spend more of their resources on the military. Governments that ally, conversely, will spend less on the military.

Despite a straightforward observable implication on the substitutability of arms and alliances, empirical support is mixed. Several scholars find evidence of a trade-off (Conybeare, 1992, 1994; Kimball, 2010; Morrow, 1993; Sorokin, 1994). Yet, others provide evidence and theorize that arms and allies can be complements (Diehl, 1994; Horowitz et al., 2017; Morgan and Palmer, 2000). For example, in some cases military spending can itself be a signal of commitment to an ally when there are fears states will engage in free-riding (Horowitz et al. 2017).

In an attempt to reconcile these competing arguments and findings, DiGiuseppe and Poast (2018) argue that to understand when states can rely on their allies and reduce their military spending, we have to appreciate variance in the credibility or quality of 
alliance commitments. This shouldn't be surprising. In an anarchic system, alliances may simply be "mere scraps of paper." Similarly, scholars and policymakers alike have long been skeptical that alliances matter alone (Kenwick et al., 2015). Instead, what seems to matter is the costs associated with breaking those alliances (Crescenzi et al., 2012; Fearon, 1997; Gibler, 2008). Against this background, DiGiuseppe and Poast (2018) argue that when the costs associated with not following through with an alliance agreement are high, allies are more likely to reduce their armaments. Democracies face higher audience and reputation costs for breaking alliance commitments (Mattes, 2012a). Consequently, having an alliance with a democratic state will result in a stronger trade-off. If leaders are uncertain about their allies' commitment, however, these leaders cannot risk reducing military spending, else external threats may be emboldened. As such, there is no observed trade-off.

DiGiuseppe and Poast's (2018) argument suggests that the ability to commit to the defense of an alliance partner increases the credibility of the alliance and thus enables states to reduce their arms. While the ability to commit due to democratic pressure is important, it is not clear that it is sufficient to eliminate doubts among allies and third parties. Many alliances are long-lasting and may have outlived their initial purposes. In addition, leadership and societal preferences for an alliance may change with elections or changes in domestic priorities (Gartzke and Gleditsch, 2004). ${ }^{4}$ Further, defense pacts made by democracies are likely to specify limits under which agreements come into force (Chiba et al., 2015), which might limit their influence on defense burdens if conditions are too specific. Beyond democratic institutions that may or may not reinforce a commitment device, what else determines the quality of an alliance in the face of these changes?

Alliance politics do not stop once the treaty is signed. Governments can and do take proactive measures to periodically signal their commitment with costly and ongoing actions (Fearon, 1997; Morrow, 1994). These signals take a variety of forms. They can include, but are not limited to, active peacetime deployments of troops or weapons, public statements of support, high-level official visits, or joint military exercises.

These extra-alliance signals serve two goals in alliances. First, signals reinforce intentions regarding the nature of a potential intervention. Second, signals help states coordinate defense strategies and burden-sharing. These signals work better when they are costly and not simply cheap talk. As such, those states that send costly signals separate themselves out as reliable and likely to intervene (Morrow, 1994). States that are unwilling to pay costs associated with maintaining an alliance risk being perceived as less willing and likely to suffer the costs of intervention as outlined in formal treaties (Morrow 2000: 70). It follows that states party to such alliances will have a greater incentive to invest in their security as they will have less confidence in their ally's willingness to intervene.

The signals that are sent to reinforce alliance commitments might not even have a practical purpose, such as increasing the probability of victory in war. They might instead be pure signals. For example, after developing long-range nuclear delivery systems, the US kept intermediate-range nuclear weapons deployed in Europe at great expense. O'Neill (1990) argues that this wasteful "burning" of money sent a strong signal to the Soviet Union of the US commitment that a less-committed ally would not have made. 
We argue that such signals of commitment reduced the imperative of European allies to invest in their military because it reduced the risk of conflict and signaled that the US was willing to contribute significant resources to their defense.

Signals, such as deploying troops or nuclear weapons, also matter because they increase the costs of not following through with an alliance commitment. As such, they increase the costs paid during peacetime, but also increase the cost of abandoning an ally in the event of war. Allies risk the destruction of their equipment or the death and capture of troops if they abandon their alliance commitment. As a result, these costly signals increase the credibility that a state will follow through on formalized alliance promises.

This signaling argument extends beyond military or weapon deployments. McManus (2018) argues that leader-specific actions, such as speeches or state visits, also signal commitment. When leaders make personal gestures of support towards foreign countries, it increases the cost of inaction in case of a crisis. That audience cost is tied directly to the leader and reinforces defensive agreements that may have been agreed upon by previous leaders.

Non-deployment signals also convey information regarding the major power's confidence in the durability of the current government. Malis and Smith (2021) claim that state visits inform would-be domestic opponents that the major power has information regarding the visited government's ability to stay in power. This information stems from the fact that major powers will not waste a leader's time visiting states that will not continue to provide policy concessions in the future and that they will not continue to support. Malis and Smith (2021) show that these visits deter internal challenges to the government. These signals should also inform and deter external challengers as well.

While signals can improve the quality of an alliance, there is considerable variance in where states decide to supplement their alliances with additional action intended to reassure and deter. This is because they are costly, either materially or politically, and not easily granted. These costs can be borne in the monetary costs of deploying troops, munitions, or foreign aid. There are also opportunity costs. With fixed resources, the US and other powerful allies must decide where resources will be deployed most effectively. With leader visits and other personal gestures of support, the opportunity costs grow more severe as a leader's time is scarce. Simply, countries may want to provide signals of support for all allies. However, scarcity forces them to focus support where it most closely aligns with a state's priorities. This generates variance in where allies will send their support. This variance, we argue, is essential for states in determining when they can count on alliance partners and, subsequently, lower their own security outlays.

Variance in alliance quality will influence a state's decision to reduce arms in two ways. First, signals from an ally reassure leaders that the partner government will make good on its security commitments. As such, leaders risk reducing their military spending and partially "outsource" their security to a foreign country. Given domestic budgetary politics, reliable allies provide leaders more leeway to reallocate resources away from military spending and toward key constituents.

Next, signals of support help extend general deterrence. Third parties are an intended audience of signals of support. If signals change their perception of the costs of fighting, 
they are less likely to raise tensions and mobilize to fight a war. Existing evidence suggests that alliances that can demonstrate credibility are less likely to be the target of militarized interstate disputes (Johnson et al., 2015). Given the lower risk of conflict, these third-party states will have less demand for military spending. This follows from existing evidence indicating that the lower probability of experiencing a dispute is associated with lower military spending (Nordhaus et al., 2012).

\section{Empirical expectations}

Following the discussion above, we expect that formal alliances are insufficient to convince leaders to reduce military spending, even if leaders have incentives to reallocate budgetary resources elsewhere. Instead, only when alliance partners send additional signals of support, in conjunction with a formal agreement, should we observe reduced spending.

Our analysis focuses on military spending as the outcome of this process, as we believe this concept best captures states' internal efforts to meet security needs. In addition, we focus on defensive alliances given that these types of alliances (as opposed to consultative or non-aggression pacts) explicitly call for security burden-sharing between states. Finally, for several reasons, we focus on the US as an alliance partner. First, the US is an important case given its capacities and the sheer number of alliance commitments it maintains. Thus, the US is a key node in many security networks. It is thus not surprising that NATO and the US is the most studied case in the burden-sharing literature (Becker, 2019). Yet precisely because the US keeps many alliances, we question whether an American alliance is a sufficient signal of support. Second, focusing on the US allows us to keep the capabilities of an alliance partner constant. This reduces potential heterogeneity in alliance dynamics. Instead, we are interested in the variance of additional signals of support.

From these concepts, we posit the following conditional hypothesis:

Hypothesis 1 Higher levels of signaled support, coupled with a US defensive alliance, will lead to a decrease in internal military spending.

We also note that the relationship between military spending and signals of support is likely to be endogenous. An important predictor of the signals of support is the recent occurrence of a militarized dispute (McManus and Nieman, 2019). This relationship likely extends to threatening environments in general. These higher threats are also likely to generate higher defense budgets as states mobilize to counter threats that were not initially deterred. While the relationship is likely endogenous, it will make it harder to find support for Hypothesis 1 and thus any effect we find in support of our argument will a conservative estimate.

Alliances, of course, are themselves a signal of support. As such, one might naturally conclude that there is a conditional relationship between all signals and military spending. As Figure 1 illustrates, the US sends signals of support outside of alliances. However, alliances have a different relationship with defense burden than other types of signals. Thus, we do not necessarily expect that other types of signals, such as 


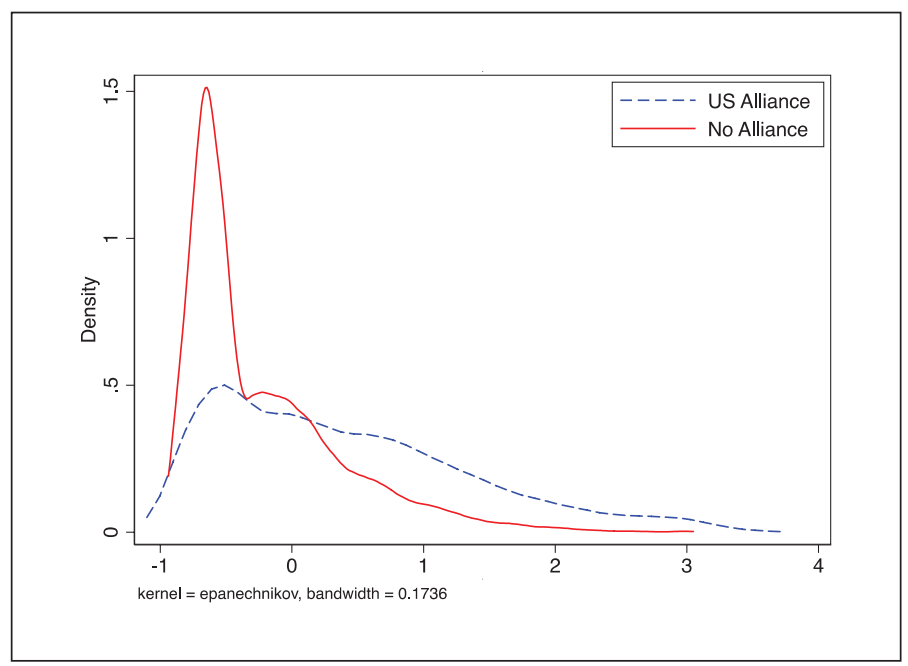

Figure I. Distribution of signals of support to US allies. The dashed and solid lines, respectively, indicate the kernel density estimate of the latent signaled support measure for those that are US allies and those that are not.

troop deployments, have an effect that is conditional on alternative signals for supports. There are several reasons for this expectation. First, US alliances are quite common. In our sample, which we describe below, seventy states have a defensive alliance with the US and over 115 countries have some type of alliance agreement with the US. Given the number of alliances, signing an alliance with the US is not necessarily an informative signal alone. Consistent with this, McManus and Nieman (2019) find that alliances contribute little to their latent measure of major power support for the US. They speculate that this is a function of the US caring more about the security of some states versus others. Examining other types of signaled support allows us to determine whose security the US is concerned with.

In addition, alliances are usually long-lasting agreements, especially asymmetric alliances (Bennett, 1997). The relative permanence of alliances differentiates alliances from other signals in two important ways. First, alliances are signed in the "shadow of war" (Morrow, 1991: 63), but over time the threats that prompted an alliance may have changed. These dynamics raise the credibility of alliances. Other types of signals help reassure American allies that the US remains committed to intervening against external threats, even if the nature of the external threat has changed.

Finally, by themselves, alliances do not impose material costs on the US or its partners beyond the initial investment in coordination. Morrow (1991) argues that without policy coordination or signals that allies have shared security interests, alliances lack credibility. Troop deployment, military exercises, and other types of signaled support are byproducts of policy coordination and signal similar interests. Instead of assuming that these signals are inherent to alliances, we argue that these types of signaled support vary 
from the US, which should affect states' expectations of the probability that the US will intervene.

As we discussed above, signals allow for the reduction in military spending because they signal commitment between allies, but they are also observed by potential adversaries (McManus, 2018). If the US credibly demonstrates that it will defend the security interests of an ally, that ally's rivals will be less likely to initiate or escalate conflict. With the lower probability of war, allies should reduce military spending, as argued above. The same logic should extend to these allies' rivals. If a state has strong confidence that a potential target will receive support in a time of crisis, it will have less of an incentive to arm for offensive purposes. Thus, we should observe that the rivals of states that receive strong signals of support should also reduce their military spending.

Hypothesis 2 Higher levels of signaled support, coupled with a US defensive alliance, will lead to a decrease in internal military spending in the allied state's rivals.

Our expectation of a rival's spending behavior as a function of signaled support is consistent with previous research that shows that some signaling, such as troop deployment, can have regional ramifications on defense spending (Allen et al., 2017). Our argument may also help explain why previous research on alliances and changes to defense burdens shows mixed results. If a credible alliance allows allies to reduce their military expenditures, simply comparing changes in military expenditures between those with credible military alliances and those without would underestimate the effect of alliances. If non-alliance states are also reducing their military expenditures in response to signals of support, differences between allied and non-allied states would be muddled, representing a lower bound effect.

\section{Empirical analysis: data}

To conduct our analysis, we adopt a country-year analysis of non-major power states with available data from the years 1960-2010. As is common with studies of military effort, our dependent variable is the level of military expenditure over gross domestic product (Fordham, 2004; Goldsmith, 2007). We construct this variable with data from the Correlates of War project and World Bank development indicators (Singer, 1987). We rely on military expenditure to retain consistency with existing work. However, we acknowledge the measure has a few weaknesses. Namely, the measure fails to capture actual capabilities as military spending can be used for domestic security purposes as well. While more nuanced variables are available, they lack the temporal and cross-national scope necessary for this study.

To operationalize alliance commitments, we rely on the Alliance Treaty and Obligations (ATOP) dataset (Leeds et al., 2002). We focus primarily on the presence of a defense pact with the US, as these commitments require a clear indication that the US will use force and shift expectations about the costs and outcome of a conflict that are essential in deterrence. Consultation pacts and neutrality pacts can impact potential conflicts but do so in a less consequential manner. Offensive alliance agreements are 
generally formed preceding a conflict and are thus unlikely to have any bearing on a country's military effort in peacetime. However, we have also run additional tests with the presence of any alliance commitment with the US to demonstrate the robustness of our findings.

Measuring US signals of support to allies is more challenging. States have a menu of different options to signal support for other states. Further, scholars have no clear expectations about the preference ordering of these signals nor expectations regarding when one signal will be deployed over another. To overcome this problem, McManus and Nieman (2019) have constructed a single variable to capture multiple signals of support with a Bayesian latent measurement model. The measure captures seven different possible signals. These include formal alliances but also visits by country leaders, joint military exercises, nuclear deployments, arms transfers, troop deployments, and leader statements of support. The method generating the data considers that the weight of these actions is unequal and that some actions may occur without the intention to signal support. Instead of arbitrarily assuming that one signal matters more than another, the measurement model allows the data to determine the relative importance of each action. This is important to test our argument given that the US may send multiple signals simultaneously. Those actions that correlate with the use of other actions hold greater weight in the final construction of the latent variable. We also demonstrate that the results largely hold using each of the signals independently.

Given that we are interested in the conditional effect of alliances and signals of support, we re-estimate McManus and Nieman's (2019) measure, excluding alliances as a component. We find that our amended measure of support (without alliances) and the original measure (with alliances) are highly correlated $(\rho=0.96)$. This is expected given that McManus and Nieman find that alliances contribute little to American signals of support.

Figure 1 shows the distribution of this latent variable for both states that have formal alliance commitments from the US (dashed) and those that are not (solid). Higher values indicate greater signals of support. As one would expect from the variable construction, US allies attract higher support than those states that do not. Yet, the figure makes clear that there is considerable variation in the level of signaled support across allies. ${ }^{5}$

We include several control variables in our empirical analysis to address the potential for confounding. Existing research points to a strong relationship between regime type and military expenditure. Democracies generally invest less in the military, relative to other priorities, than more autocratic states (Fordham and Walker, 2005; Goldsmith, 2007). The US might also engage in more signals with other democracies for a variety of reasons. We employ the "polyarchy" measure from the V-Dem project as our primary indicator of regime type (Pemstein et al., 2018).

States involved in an ongoing external or internal conflict are likely to spend more on defense than those at peace. Additionally, our formal and non-formal indicators of support include variables, such as alliances, leadership visits, or arms transfers, that are probably more likely to begin or occur during crises. To protect against this potential confounding, we control for the presence of a militarized interstate dispute (MID) (Ghosn et al., 2004) and the presence of a civil conflict (Eck and Pettersson, 2018; Gleditsch and Strand, 2002). ${ }^{6}$ Similarly, states that are not involved in a conflict but reside in a hostile 
neighborhood may be incentivized to invest more in military spending but also experience more interaction with major powers that seek to manage the situation. We thus control for a state's security environment with Markowitz and Fariss's (2018) latent measure. This measure captures a state's proximity to states with which it has incompatible interests and thus captures the degree by which a state resides in a neighborhood with states that do not share its interests.

Since wealthy states have more resources to dedicate towards defense, we control for a state's wealth with the natural log of gross domestic product. This is important because larger states might also garner more attention from allies and thus potentially confound the hypothesized relationship. We also control for population as larger states may present more opportunities for engagement and may achieve economies of scale in military spending. Lastly, we include year-fixed effects to address any yearly fluctuations in US security engagement with the world. However, the omission of these fixed effects does not change our central conclusions.

\section{Empirical analysis: results}

To assess the hypothesized conditional relationship, we regress military burden on the binary US alliance indicator, signals of support, and their interaction. ${ }^{7}$ The signals of support variable is a product of a measurement model, and each observation has different levels of uncertainty around the estimated value. To account for this uncertainty, we follow McManus and Nieman (2019) and take five draws from the posterior distribution of the latent variable and run separate models with each of the draws. We then combine these models to generate point estimates and standard errors using Rubin's (1987) multiple imputation formula. ${ }^{8}$

Table 1 presents the coefficients for four models. The only difference between the first two models is that the first model excludes a lagged dependent variable, while the second model includes it. Lagging the dependent variable is potentially important as military spending is known to suffer from budgetary inertia (Nordhaus et al., 2012).

To ease interpretation of the interaction terms and their constituent parts, we plot the marginal effect of a defensive alliance with the US on military burden in the four panels of Figure 2 (Brambor et al., 2006). Each panel presents the marginal effect and the 95\% confidence intervals around the estimate across the minimum to maximum levels of signals of support. Each panel also plots the percentage of observations for different levels of US protege support only for those states that already have an existing alliance with the US.

The first panel of Figure 2 shows that the effect of an alliance agreement on military spending is not statistically different from zero, based on the model excluding a laggeddependent variable (Model 1) when there are no or very few additional signals sent. It also shows that, as the level of the signals of support variable grows, a US alliance has a negative relationship with military burden. The second panel indicates that the inclusion of the lagged dependent variable (Model 2) does not substantively alter our conclusions. The first two panels indicate statistical significance at higher levels of signals of support but what does this mean substantively? Based on the estimates of Model 2, an alliance decreases military spending by about $0.9 \%$ of GDP when states send signals at the 90th 
Table I. The effect of US defense pacts and protege support on defense burden.

\begin{tabular}{|c|c|c|c|c|}
\hline & $(\mathrm{I})$ & $(2)$ & (3) & $(4)$ \\
\hline US defense pact & $\begin{array}{c}-0.002 \\
(0.002)\end{array}$ & $\begin{array}{c}-0.003 \\
(0.002)\end{array}$ & $\begin{array}{c}-0.003 \\
(0.003)\end{array}$ & $\begin{array}{c}-0.002 \\
(0.002)\end{array}$ \\
\hline US signals & $\begin{array}{l}0.004 * * \\
(0.001)\end{array}$ & $\begin{array}{l}0.006 * * \\
(0.001)\end{array}$ & $\begin{array}{l}0.006 * * \\
(0.001)\end{array}$ & $\begin{array}{c}0.004^{* *} \\
(0.001)\end{array}$ \\
\hline US defense pact * US signals & $\begin{array}{c}-0.003 * * \\
(0.001)\end{array}$ & $\begin{array}{c}-0.004 * * \\
(0.001)\end{array}$ & $\begin{array}{c}-0.004^{* *} \\
(0.001)\end{array}$ & $\begin{array}{c}-0.003^{* *} \\
(0.001)\end{array}$ \\
\hline V-Dem polyarchy & $\begin{array}{c}-0.005 * * \\
(0.002)\end{array}$ & $\begin{array}{c}-0.004 * * \\
(0.001)\end{array}$ & $\begin{array}{c}-0.005 * * \\
(0.001)\end{array}$ & $\begin{array}{c}-0.005^{* *} \\
(0.002)\end{array}$ \\
\hline GDP & $\begin{array}{l}0.000 * * \\
(0.000)\end{array}$ & $\begin{array}{l}0.000 * * \\
(0.000)\end{array}$ & $\begin{array}{l}0.000 * * \\
(0.000)\end{array}$ & $\begin{array}{c}0.000 * * \\
(0.000)\end{array}$ \\
\hline Competitive environment & $\begin{array}{c}0.369 * * \\
(0.128)\end{array}$ & $\begin{array}{c}0.282 * \\
(0.122)\end{array}$ & $\begin{array}{c}0.25 I^{*} \\
(0.126)\end{array}$ & $\begin{array}{c}0.359 * * \\
(0.127)\end{array}$ \\
\hline MID & $\begin{array}{c}0.001 * \\
(0.000)\end{array}$ & $\begin{array}{l}0.001 * * \\
(0.000)\end{array}$ & $\begin{array}{l}0.002 * * \\
(0.000)\end{array}$ & $\begin{array}{c}0.001 \text { ** } \\
(0.000)\end{array}$ \\
\hline Intrastate conflict & $\begin{array}{c}0.002^{*} \\
(0.001)\end{array}$ & $\begin{array}{l}0.003 * * \\
(0.001)\end{array}$ & $\begin{array}{l}0.003 * * \\
(0.001)\end{array}$ & $\begin{array}{c}0.002^{*} \\
(0.001)\end{array}$ \\
\hline Log of population & $\begin{array}{c}-0.001 * * \\
(0.000)\end{array}$ & $\begin{array}{c}-0.001 * * \\
(0.000)\end{array}$ & $\begin{array}{c}-0.001 * * \\
(0.000)\end{array}$ & $\begin{array}{c}-0.001 * * \\
(0.000)\end{array}$ \\
\hline LDV & & $\begin{array}{l}0.255^{* *} \\
(0.060)\end{array}$ & $\begin{array}{l}0.265^{* *} \\
(0.060)\end{array}$ & \\
\hline Ln of troops & & & & $\begin{array}{c}0.001 \\
(0.001)\end{array}$ \\
\hline US defense pact $*$ Log of troops & & & & $\begin{array}{c}-0.001 \\
(0.001)\end{array}$ \\
\hline Constant & $\begin{array}{l}0.01 I^{* *} \\
(0.004)\end{array}$ & $\begin{array}{l}0.014^{* *} \\
(0.004)\end{array}$ & $\begin{array}{l}0.015^{* *} \\
(0.004)\end{array}$ & $\begin{array}{l}0.011 \text { (** } \\
(0.004)\end{array}$ \\
\hline Observations & 5323 & 5251 & 4631 & 5323 \\
\hline
\end{tabular}

Note: Each model includes year-fixed effects. Standard errors in parentheses. Model 3 excludes NATO Countries from the analysis. MID = militarized interstate dispute. $L D V=$ lagged dependent variable. $*_{p}<.05,{ }^{* *} p<.01, * * * p<.001$.

percentile level (1.77). By comparison, the existence of a militarized interstate dispute and intrastate conflict are associated with a $0.1 \%$ and $0.2 \%$ increase in military spending as a proportion of GDP.

One worry about our initial findings is that a sizable portion of US alliance commitments are contained within NATO. NATO has had as many as 30 members, and it has many provisions that increase both political and military interactions. Further, NATO's size is often invoked in debates about "free-riding." As such, our findings may reflect the burden-sharing dynamics within a particular, large, and unique alliance rather than a more general finding (Becker and Malesky, 2017). In Figure 2c, we present the marginal effect of a defense pact resulting when we replicate Model 2 but exclude NATO members from the sample (Model 3). The results are practically identical to the findings we observe in the previous two models. 


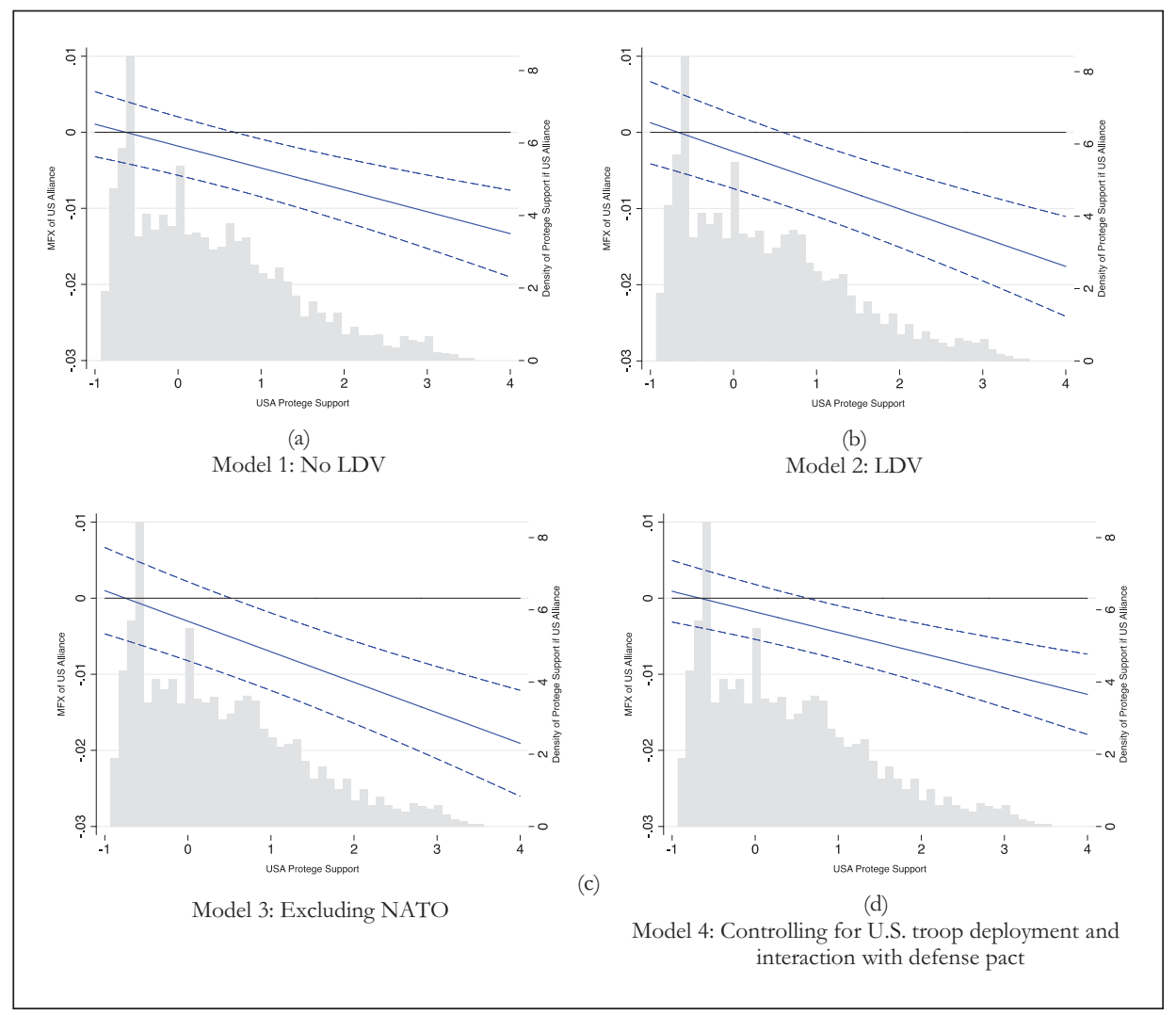

Figure 2. Marginal effect of a US defense pact across US signaled support. Each panel indicates the marginal effect of US alliance across values of US protege support. The solid lines indicate the estimates marginal effect, and the dashed lines indicate the $95 \%$ confidence intervals. The histogram in each panel indicates the distribution of median US protege support for each country-year. The panels correspond with the models presented in Table I.

Another concern about our findings is that they are not capturing the effect of signals of support in general, but rather only one element of our signal variable. Notably, several scholars have found that the deployment of US troops is associated with both a lower military burden and a reduction in a country's military personnel (Allen et al., 2016, 2017; Martinez Machain and Morgan, 2013). To demonstrate that our findings are not solely the result of troop deployments, we take several steps. First, we control for the log of US troops deployed in a country and the interaction of US troop deployment with our alliance variable (Model 4). Figure 2d presents the marginal effect for this model and demonstrates that this does not fundamentally alter our results. Next, as we discuss below, we estimate the conditioning effect of each element used in the McManus and Nieman (2019) latent variable on the relationship between alliance commitments and military burden. 


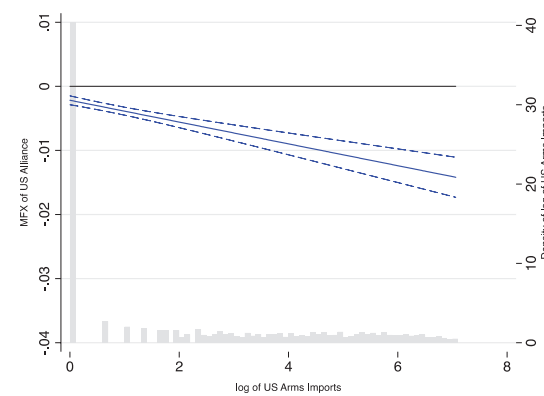

(a) $\log$ of arms transfers

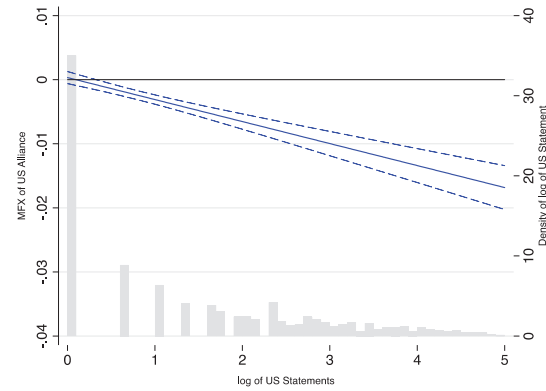

(c) $\log$ of statements

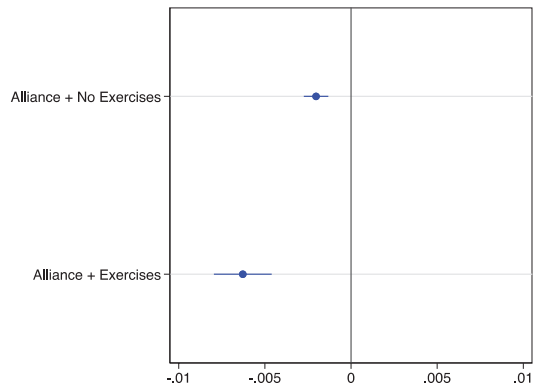

(e) military exercises

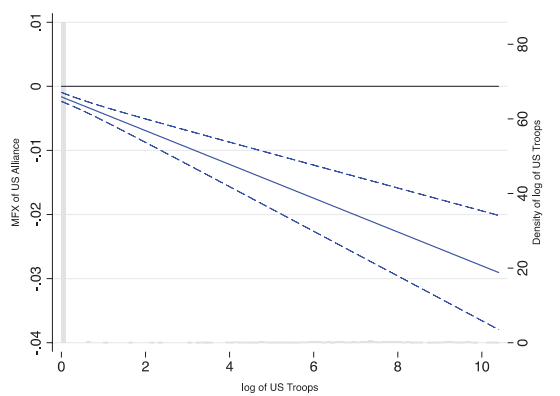

(b) $\log$ of troops

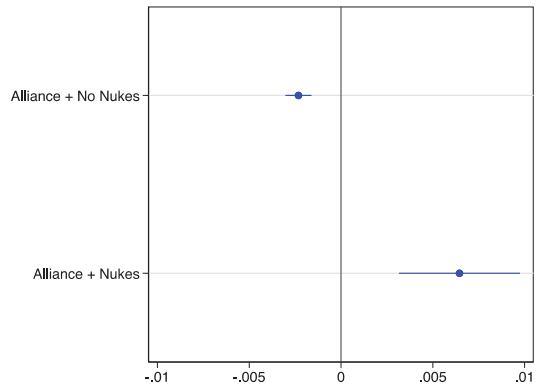

(d) nuclear weapon deployment

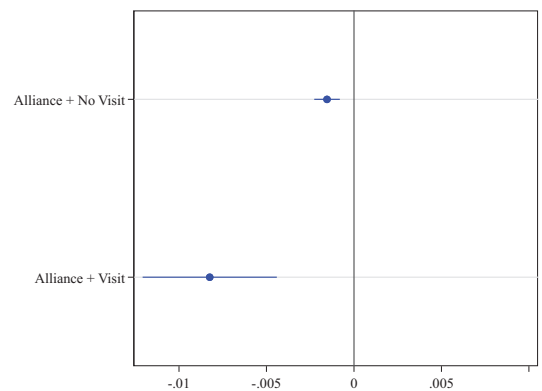

(f) leadership visits

Figure 3. Marginal effect of US alliance across individual signals. Each panel illustrates the marginal effect of a US defense pact across conditioning variables from separate models (available in the Supplemental Appendix). Each model includes year-fixed effects. In panels a-c, the dashed lines indicate the $95 \%$ confidence intervals around the estimated marginal effect (solid). In panels $d-f$, the dot is the point estimate, and the lines indicate the $95 \%$ confidence intervals.

\section{Disaggregating signals of support}

The findings thus far demonstrate support for our argument. However, one might argue that our findings are the product of the reliance on an opaque variable. In Figure 3, we 
Table 2. The effect of US defense pacts and protege support on the defense burden of rivals.

\begin{tabular}{|c|c|c|c|c|}
\hline & (5) & (6) & (7) & $(8)$ \\
\hline $\operatorname{LDV}_{j}$ & & $\begin{array}{c}0.006 \\
(0.038)\end{array}$ & & $\begin{array}{c}0.029 \\
(0.044)\end{array}$ \\
\hline US defense pact $t_{i}$ & $\begin{array}{c}-0.005 \\
(0.004)\end{array}$ & $\begin{array}{c}-0.007 \\
(0.004)\end{array}$ & $\begin{array}{l}-0.006 \\
(0.005)\end{array}$ & $\begin{array}{c}-0.007 \\
(0.005)\end{array}$ \\
\hline US signals ${ }_{i}$ & $\begin{array}{l}0.013^{* *} \\
(0.002)\end{array}$ & $\begin{array}{l}0.015^{* *} \\
(0.002)\end{array}$ & $\begin{array}{l}0.011 \text { ** } \\
(0.002)\end{array}$ & $\begin{array}{l}0.011 \text { ** } \\
(0.002)\end{array}$ \\
\hline US defense pact ${ }_{i} *$ US signals i $_{i}$ & $\begin{array}{c}-0.006 * * \\
(0.002)\end{array}$ & $\begin{array}{l}-0.006 * * \\
(0.002)\end{array}$ & $\begin{array}{c}-0.005^{*} \\
(0.002)\end{array}$ & $\begin{array}{l}-0.006 \text { ** } \\
(0.002)\end{array}$ \\
\hline V-Dem polyarchy ${ }_{i}$ & $\begin{array}{c}-0.006 \\
(0.006)\end{array}$ & $\begin{array}{c}-0.007 \\
(0.005)\end{array}$ & $\begin{array}{l}-0.011 \\
(0.007)\end{array}$ & $\begin{array}{c}-0.010 \\
(0.006)\end{array}$ \\
\hline $\mathrm{GDP}_{\mathrm{i}}$ & $\begin{array}{c}0.000 \\
(0.000)\end{array}$ & $\begin{array}{c}0.000 \\
(0.000)\end{array}$ & $\begin{array}{c}0.000 \\
(0.000)\end{array}$ & $\begin{array}{c}0.000 \\
(0.000)\end{array}$ \\
\hline Competitive environment $_{\mathrm{i}}$ & $\begin{array}{c}0.420 \\
(0.647)\end{array}$ & $\begin{array}{c}0.602 \\
(0.554)\end{array}$ & $\begin{array}{c}-0.898 \\
(0.694)\end{array}$ & $\begin{array}{c}-0.589 \\
(0.643)\end{array}$ \\
\hline $\mathrm{MID}_{\mathrm{i}}$ & $\begin{array}{c}0.003 * \\
(0.001)\end{array}$ & $\begin{array}{l}0.004 * * \\
(0.001)\end{array}$ & $\begin{array}{l}0.006 * * \\
(0.002)\end{array}$ & $\begin{array}{l}0.005^{* *} \\
(0.002)\end{array}$ \\
\hline Intrastate conflict $_{i}$ & $\begin{array}{l}0.006 * * \\
(0.002)\end{array}$ & $\begin{array}{l}0.008^{* *} \\
(0.002)\end{array}$ & $\begin{array}{l}0.008 * * \\
(0.002)\end{array}$ & $\begin{array}{l}0.008 * * \\
(0.002)\end{array}$ \\
\hline Log of population ${ }_{j}$ & $\begin{array}{c}-0.003^{* *} \\
(0.000)\end{array}$ & $\begin{array}{l}-0.003 * * \\
(0.000)\end{array}$ & $\begin{array}{l}-0.006 * * \\
(0.001)\end{array}$ & $\begin{array}{c}-0.006 \text { ** } \\
(0.001)\end{array}$ \\
\hline V-Dem polyarchy ${ }_{j}$ & & & $\begin{array}{c}0.006 \\
(0.005)\end{array}$ & $\begin{array}{c}0.004 \\
(0.005)\end{array}$ \\
\hline $\mathrm{GDP}_{\mathrm{j}}$ & & & $\begin{array}{c}-0.000 \\
(0.000)\end{array}$ & $\begin{array}{c}-0.000 \\
(0.000)\end{array}$ \\
\hline Competitive environment $t_{j}$ & & & $\begin{array}{l}\text { I.706** } \\
(0.569)\end{array}$ & $\begin{array}{l}\text { I.578** } \\
(0.605)\end{array}$ \\
\hline US defense pact ${ }_{j}$ & & & $\begin{array}{c}0.001 \\
(0.004)\end{array}$ & $\begin{array}{c}-0.001 \\
(0.004)\end{array}$ \\
\hline US signals ${ }_{j}$ & & & $\begin{array}{l}0.004 * * \\
(0.001)\end{array}$ & $\begin{array}{l}0.005^{* *} \\
(0.001)\end{array}$ \\
\hline $\mathrm{MID}_{\mathrm{j}}$ & & & $\begin{array}{l}-0.004 * * \\
(0.002)\end{array}$ & $\begin{array}{c}-0.003 \\
(0.002)\end{array}$ \\
\hline Intrastate conflict ${ }_{j}$ & & & $\begin{array}{l}-0.003 \\
(0.002)\end{array}$ & $\begin{array}{c}-0.000 \\
(0.002)\end{array}$ \\
\hline Log of population $_{j}$ & & & $\begin{array}{l}0.003 * * \\
(0.001)\end{array}$ & $\begin{array}{l}0.003 \text { *** } \\
(0.001)\end{array}$ \\
\hline Constant & $\begin{array}{c}0.03 I^{*} \\
(0.012)\end{array}$ & $\begin{array}{c}0.029 * \\
(0.013)\end{array}$ & $\begin{array}{c}0.023^{*} \\
(0.012)\end{array}$ & $\begin{array}{c}0.023^{*} \\
(0.011)\end{array}$ \\
\hline Controls $_{\mathrm{i}}$ & $x$ & $x$ & $x$ & $x$ \\
\hline Controls & & & $x$ & $x$ \\
\hline Year fixed-effects & $x$ & $x$ & $x$ & $x$ \\
\hline Observations & 2,990 & 2,830 & 2,694 & 2,635 \\
\hline
\end{tabular}

Note: Each model includes year-fixed effects; control variable coefficients are not shown. Standard errors in parentheses. MID = militarized interstate dispute. $L D V=$ lagged dependent variable.

$* p<.05, * * p<.01, * * * p<.001$. 


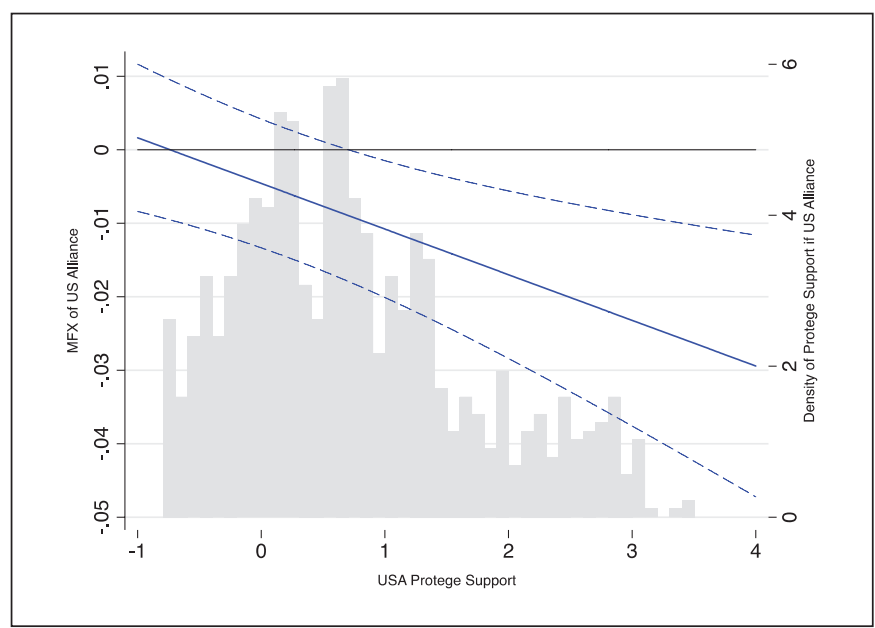

Figure 4. Marginal effect of a US alliance on its ally's strategic rival's military effort across US signals of support. The solid line indicates the estimated marginal effect. The dashed lines indicate the $95 \%$ confidence intervals. These estimates were produced using the values in Model 5 of Table 2.

present marginal effect plots in which we estimated six different models, each estimating the effect of a defense pact conditional on a single element of the latent variable used in the preceding section and omitting the other signals. We learn several interesting things from disaggregating the measure. First, in five of the six measures, we see that our expected relationship holds. An alliance with the US has either no relationship or a small negative relationship with military burden at low levels of the support signal. Among the continuous variables, we see the negative relationship increase as the value of the signal of support increases. Among two binary conditioning variables (leader visits and military exercises), we observe a statistically significant and negative difference from the base condition. The only signal in which our hypothesized relationship does not hold is for nuclear deployments. It is difficult for us to determine why. Following research from Fuhrmann and Sechser (2014), we speculate that nuclear deployments might be a very strong signal of support that is likely to draw an alliance partner into war. As such, the selection process for this signal might be unique. Yet, more research is needed here.

While we expected the relationship to hold for costly actions such as arms transfers, troop deployments, and military exercises, we also find that this relationship also holds for cheaper gestures: statements of support and leader visits (Figure $3 \mathrm{c}$ and f). One possibility is that statements of support are highly correlated with more costly signals. However, further analysis reveals that the relationship holds even when controlling for more costly signals (troop deployments) and their interaction with defense pacts.

In all, the disaggregation of the signals of support measure lends further empirical support to our argument. Where signals are absent, there will be little benefit from alliances in terms of military burden reduction. Yet, as signals grow, countries have greater confidence to enjoy the fiscal and political benefits of alliances by reducing their military effort. 


\section{Testing the deterrent hypothesis}

To test our expectation of the deterrent effect of signaled support in Hypothesis 2, we examine the military effort of rivals. We test whether signaled support from the US to another state affects that state's rival. For example, when the US recently increased military exercises with Colombia, these were designed to not only reassure Colombia of US commitment but also to deter Venezuela from any military action against Colombia. ${ }^{9}$ As a result, we expect that Colombia can decrease its military outlays because conflict with Venezuela is less likely. In addition, we expect that Venezuela, if deterred, would also be more likely to decrease military outlays and instead use fiscal resources to satisfy key domestic constituents. ${ }^{10}$ With this logic, we replicate the results in Table 1 but substitute the military spending of a state $(i)$ for its rival $(j)$, if a rival exists. ${ }^{11}$ To identify rivalries, we use Thompson and Dreyer's (2011) data on strategic alliances. We then replace state $i$ 's military spending value for state $j^{\prime} s$.

Table 2 reports the results. Model 1 shows that if state $i$ has a defensive pact with the US, $i$ 's rival, $j$, will decrease military spending, though that decrease is not statistically different than zero. However, the interaction term shows that if the US couples that defensive pact with added signals of support, then the rival decreases its military spending even more. This conditional effect persists when we include the lagged dependent variable in model 2 and when we include additional controls that capture characteristics of rival $j$ in models 3 and 4 . To ease interpretation, we plot the interaction effect from Model 5 in Figure 4.

These results support our assertion that the US uses deployment, informal, and leaderspecific signals to not only reassure allies of American commitment but also to deter threats against these allies. When American defensive pacts are coupled with added signals of support, American allies and these allies' rivals are more likely to be convinced that the security environment is secured. This allows both the allies and their rivals to divert military fiscal resources elsewhere.

\section{Further analyses}

Our analysis shows that US signals supplement alliance commitments and are strongly associated with a reduction in the military spending of US allies and the strategic rivals of those allies. While we have provided strong evidence to support this conclusion, our study has several limitations thus far. First, our analysis does not demonstrate that this relationship extends beyond the US and its allies. US allies are generally more democratic and democratic states are also more disposed to engage in an internal-external arms trade-off. Thus, our findings may not extend beyond the US security network. We ran additional checks and find that, while also controlling for US alliances and signals, French and UK alliances do not have a similar effect on military spending. However, this might be because the UK and France are embedded in the US security network. We do find that an alliance with Russia has a negative impact on military spending when more signals are deployed. We present these findings in the Supplemental Appendix but caution that further research is needed to demonstrate the robustness of these results and demonstrate that this relationship applies beyond major power alliances. 
Another potential threat to our inferences is that new alliances may be prone to experience more signals. New alliances come with many requirements for political and military cooperation that might increase the observations of signals of support. This may also coincide with a time when alliances are their most credible as common security interests are easily observed. To demonstrate that this is not the case, we present results in the Supplemental Appendix that demonstrates that the conditioning effect of signals of support is strongest for alliances that are over 10 years old relative to newer alliances. This finding is consistent with our expectations. Older alliances are most likely to be formed by previous leaders and governments. Signals of support provide renewed assurance that enthusiasm for the alliances remains despite leadership changes.

\section{Conclusion}

When do states take advantage of the security benefits of alliance agreements and reduce military spending? In this study, we argued that formal alliances alone are limited in their ability to offer states enough confidence in their alliance partner's commitment to allow them to reduce their military spending. However, additional signals of support reaffirm a commitment so allies will be more likely to reduce arms. Our empirical tests showed that a US alliance commitment has little or no association with a state's military effort absent additional signals. However, when a US alliance commitment is combined with signals of American support, we are then more likely to see lower military spending compared to states that do not have an alliance agreement. In addition, rivals of these allies are also more likely to reduce their military spending as these signals of support are effective deterrents.

This study contributes to several literatures. First, we identify conditions on the credibility of alliances. Second, we demonstrate how this credibility subsequently conditions the arms-versus-alliance trade-off. Third, we find that the arms-versus-alliance trade-off applies to rivals as well as allies. Finally, we connect recent research on the effectiveness of informal and leader-specific signals to implications related to alliances. For example, recent studies have produced conflicting evidence on the effectiveness of signals in deterring third-party aggression in alliance agreements (Fuhrmann and Sechser, 2014; McManus and Nieman, 2019). This previous literature has relied on the ability of alliances to deter militarized interstate disputes to test the importance of signals. Our study examines an alternative implication of signals of support, the willingness of proteges to reduce armaments. In sum, our findings suggest that formal treaties matter, but matter most when bolstered by additional signals of support.

Our study also raises additional questions that should be evaluated in future research. For example, credible alliances free up domestic resources, but what would allies spend their money on instead? Given that spending decisions create domestic winners and losers, we expect allies to spend domestic resources to satisfy key constituents (Allen and DiGiuseppe, 2012; Kimball, 2010; Narizny, 2003). As a result, leaders in these countries should have longer tenures. In addition, given that rivals also have incentives to reduce military spending, the rivals' leaders should also be able to stay in power longer. Future research should further examine the political implications of the arms-versus-alliance trade-off. 
Lastly, our analysis speaks to ongoing policy debates. The US has consistently argued for some allies to make a greater contribution to joint defense. However, under the Trump administration, active steps to reduce other areas of coordination to encourage states to contribute more. ${ }^{12}$ Our results suggest that reducing additional signals of support may have the desired effect of increased military spending. However, it may also undermine the alliance as the military spending of rivals increases. This suggests that deterrence is weakened, and the alliance's credibility is called into question. Our results potentially suggest that limiting extra-alliance signals of support is likely to be an ineffective strategy to reduce free riding among allies.

\section{Acknowledgements}

The authors would like to thank Jordan Becker for early comments and Nina Waals for research assistance. An early version of this paper was presented at the 2019 Politicologenetmaal conference.

\section{Funding}

The author(s) disclosed receipt of the following financial support for the research, authorship, and/ or publication of this article: This article was partially supported by European Research Council Grant \#852334.

\section{ORCID iD}

Matthew DiGiuseppe iD https://orcid.org/0000-0003-0823-0436

\section{Supplemental material}

Supplemental material for this article is available online.

\section{Notes}

1. https://www.defense.gov/Explore/News/Article/Article/1282738/dod-announces-start-ofexercise-ulchi-freedom-guardian/igphoto/

2. When referring to allies, we imply alliances with a defense pact.

3. As declared by German Chancellor Bethmann-Hollweg in regard to the Guarantee of Belgian Neutrality (Cooke and Stickney, 1931: 382)

4. Further, alliances themselves, while often seen as providing information to third parties, often have vague language that might allow them avoid harm to their reputation or audience costs if they decline to come to an ally's aid (Benson, 2012).

5. In theory, signals from all allies should have an influence on military effort. However, the measure is only available for states identified as major powers by the Correlates of War Project (the US, the United Kingdom, France, Russia, and China). There is not an obvious way to summarize a state's level of major power support across these measures. This is one of the reasons why our central analysis focuses on the impact of an alliance and signals of support with the US. We present additional tests in the Supplemental Appendix to examine if the results are robust to the presence of relationships with other major powers.

6. Including MID in our model might induce post-treatment bias that might shrink the true effect size. However, in subsequent analysis, we show that the exclusion of MIDs didn't substantively change the effect size. 
7. We include an autocorrelation structure in all models.

8. The point estimates are calculated with the following formula: $\frac{1}{5} \sum_{k}^{5} \beta_{k}$. The standard errors are calculated with the following formula: $\sqrt{\frac{1}{5} \sum_{k}^{5} s_{k}^{2}+\left(1+\frac{1}{5}\right) \sigma_{\beta}^{2}}$.

9. https:/www.defense.gov/Explore/News/Article/Article/2062024/us-colombian-parat roopers-to-participate-in-airborne-assault-exercise/

10. We acknowledge that states such as Venezuela may have domestic or diversionary incentives to continue to escalate a conflict with Colombia. However, if US support is credible, Venezuela is less likely to escalate.

11. As such, we only include states with rivals in our analyses.

12. We note that in NATO some troop withdrawals, like those observed in Germany, were offset by troop increases in other areas of multilateral alliance.

\section{References}

Allen MA and DiGiuseppe MD (2012) Tightening the belt: Sovereign debt and alliance formation. International Studies Quarterly 57(4): 647-659.

Allen MA, Van Dusky-Allen J and Flynn ME (2016) The localized and spatial effects of us troop deployments on host-state defense spending. Foreign Policy Analysis 12: 674-694.

Allen MA, Flynn ME and Van Dusky-Allen J (2017) Regions of hierarchy and security: us troop deployments, spatial relations, and defense burdens. International Interactions 43(3): 397-423.

Altfeld M (1984) The decision to ally. Western Political Quarterly 37(4): 523-544.

Barnett MN and Levy JS (1991) Domestic sources of alliances and alignment: the case of Egypt, 1962-73. International Organization 45(3): 369-395.

Becker JM (2019) Accidental rivals? EU fiscal rules, NATO, and transatlantic burden-sharing. Journal of Peace Research 56(5): 697-713.

Becker JM and Malesky E (2017) The continent or the "grand large"? Strategic culture and operational burden-sharing in NATO. International Studies Quarterly 61(1): 163-180.

Bennet DS (1997) Testing alternative models of alliance duration, 1816-1984. American Journal of Political Science 41(3): 846-878.

Benson B (2012) Constructing International Security. Cambridge, UK: Cambridge University Press.

Bialik K (2017) U.S. active-duty military presence overseas is at its smallest in decades. Available at: https://www.pewresearch.org/fact-tank/2017/08/22/u-s-active-duty-military-presenceoverseas-is-at-its-smallest-in-decades/

Brambor T, Clark WR and Golder M (2006) Understanding interaction models: improving empirical analyses. Political Analysis 14(1): 63-82.

Cappella Zielinski R, Fordham BO and Schilde KE (2017) What goes up, must come down? The asymmetric effects of economic growth and international threat on military spending. Journal of Peace Research 54(6): 791-805.

Chiba D, Johnson JC and Leeds BA (2015) Careful commitments: democratic states and alliance design. Journal of Politics 77(4): 968-982.

Conybeare JAC (1992) A portfolio diversification model of alliances. Journal of Conflict Resolution 36(1): 53-85.

Conybeare JAC (1994) Arms versus allies: the capital structure of military enterprise. Journal of Conflict Resolution 38(2): 215-235.

Cooke W and Stickney E (1931) Readings in European International Relations Since 1879. London, UK: Harper and Brothers Publishers. 
Crescenzi M, Kathman J, Kleinberg K, et al. (2012) Reliability, reputation, and alliance formation. International Studies Quarterly 56: 259-274.

Diehl PF (1994) Substitutes or complements? The effects of alliances on military spending in major power rivalries. International Interactions 19(3): 159-176.

Diehl PF and Goertz G (2001) War and Peace in International Rivalry. Ann Arbor, MI: University of Michigan.

DiGiuseppe M and Poast P (2018) Arms versus democratic allies. British Journal of Political Science 48(4): 981-1003.

Eck K and Pettersson T (2018) Organized violence, 1989-2017 and the data generation process. Journal of Peace Research 55(4): 535-547.

Fearon JD (1997) Signaling foreign policy interests. Journal of Conflict Resolution 41(1): 68.

Fordham BO (2002) Domestic politics, international pressure, and the allocation of American cold war military spending. The Journal of Politics 64(1): 63-88.

Fordham BO (2004) A very sharp sword: the influence of military capabilities on American decisions to use force. The Journal of Conflict Resolution 48(5): 632-656.

Fordham BO and Walker T (2005) Kantian liberalism, regime type, and military resource allocation: do democracies spend less? International Studies Quarterly 4(1): 141-157.

Fuhrmann M and Sechser TS (2014) Signaling alliance commitments: hand-tying and sunk costs in extended nuclear deterrence. American Journal of Political Science 58(4): 919-935.

Gartzke E and Gleditsch KS (2004) Why democracies may actually be less reliable allies. American Journal of Political Science 48(4): 775-795.

Ghosn F, Palmer G and Bremer S (2004) The mid3 data set, 1993âÂ ${ }^{\circ} 2001$ : procedures, coding rules, and description. Conflict Management and Peace Science 21(2): 133.

Gibler D (2008) The costs of reneging: reputation and alliance formation. Journal of Conflict Resolution 52(3): 426-454.

Gleditsch NP, Wallensteen P and Strand H (2002) Armed conflict, 1946-2001. Journal of Peace Research 39(5): 615-637.

Goldsmith B (2007) Defense effort and institutional theories of democratic peace and victory: why try harder? Security Studies 16(2): 189-222.

Horowitz MC, Poast P and Stam AC (2017) Domestic signaling of commitment credibility: military recruitment and alliance formation. Journal of Conflict Resolution 61(8): 1682-1710.

Johnson JC and Leeds BA (2011) Defense pacts: a prescription for peace. Foreign Policy Analysis 7(1): 45-65.

Johnson JC, Leeds BA and Wu A (2015) Capability, credibility, and extended general deterrence. International Interactions 41(2): 309-336.

Kenwick MR, Vasquez JA and Powers MA (2015) Do alliances really deter? The Journal of Politics 77(4): 943-954.

Kimball AL (2010) Political survival, policy distribution, and alliance formation. Journal of Peace Research 47(4): 407-419.

Lake DA (1996) Anarchy, hierarchy, and the variety of international relations. International Organization 50(01): 1-33.

Lake DA (1999) Entangling Relations: American Foreign Policy in its Century. Princeton: Princeton University Press. ISBN 0691059918.

Leeds BA (2003) Alliance reliability in times of war: explaining state decisions to violate treaties. International Organization 57(04): 801-827.

Leeds BA, Ritter JM, Mitchell SL, et al. (2002) Alliance treaty obligations and provisions, 18151944. International Interactions 28(3): 237-260.

Malis M and Smith A (2021) State visits and leader survival. American Journal of Political Science 65(1): 241-256. 
Markowitz JN and Fariss CJ (2018) Power, proximity, and democracy: geopolitical competition in the international system. Journal of Peace Research 55(1): 78-93.

Martinez Machain C and Morgan TC (2013) The effect of us troop deployment on host states' foreign policy. Armed Forces \& Society 39(1): 102-123.

Mattes M (2012a) Democratic reliability, precommitment of successor governments, and the choice of alliance commitment. International Organization 66(1): 153-172.

Mattes M (2012b) Reputation, symmetry, and alliance design. International Organization 66(04): 679-707.

McManus R (2014) Fighting words: the effectiveness of statements of resolve in international conflict. Journal of Peace Research 51(6): 726-740.

McManus R (2018) Making it personal: the role of leader-specific signals in extended deterrence. Journal of Politics 80(3): 982-995.

McManus R and Nieman MD (2019) Identifying the level of major power support signaled for protégés: a latent measure approach. Journal of Peace Research 58(3): 364-378.

McManus R and Yarhi-Milo K (2017) The logic of "offstage" signaling: Domestic politics, regime type, and major power-protégé relations. International Organization 71(4): 701-733.

Morgan TC and Palmer G (2000) A model of foreign policy substitutability: selecting the right tools for the job(s). Journal of conflict Resolution 44(1): 11-32.

Morgenthau H (1948) Politics Among Nations. The Struggle for Power and Peace. New York: Alfred A. Knopf.

Morrow JD (1991) Alliances and asymmetry: an alternative to the capability aggregation model of alliances. American Journal of Political Science 35(4): 904-933.

Morrow JD (1993) Arms versus allies: trade-offs in the search for security. International Organization 47(2): 207-233.

Morrow JD (1994) Alliances, credibility, and peacetime costs. Journal of Conflict Resolution 38(2): 270-297.

Morrow JD (2000) Alliances: why write them down? Annual Review of Political Science 3: 64-83.

Narizny K (2003) Both guns and butter, or neither: class interests in the political economy of rearmament. American Political Science Review 97(2): 203-220.

Nordhaus W, Oneal JR and Russett B (2012) The effects of international security environment on national military expenditures: a multi-country study. International Organization 66(3): 491-513.

O'Neill B (1990) The intermediate nuclear force missiles: an analysis of coupling and reassurance. International Interactions 15(3-4): 345-362.

Olson M and Zeckhauser R (1966) An economic theory of alliances. The Review of Economics and Statistics 48(3): 266-279.

Pemstein D, Marquardt KL, Tzelgov E, et al. (2018) The V-DEM measurement model: latent variable analysis for cross-national and cross-temporal expert-coded data. V-Dem Working Paper 21. 6th edn.

Plumper T and Neumayer E (2014) Free-riding in alliances: testing an old theory with a new method. Conflict Management and Peace Science. forthcoming.

Rubin DB (1987) Multiple Imputation for Nonresponse in Surveys. New York: John Wiley \& Sons.

Schelling T (1960) Arms and Influence. Cambridge, MA: Harvard University Press.

Singer JD (1987) Reconstructing the correlates of war dataset on material capabilities of states, 1816-1985. International Interactions 14: 115-132.

Smith A (1995) Alliance formation and war. International Studies Quarterly 39(4): 405-425. 
Smith J (2019) Buying a big stick: South Korea's military spending has North Korea worried. Reuters. Available at: https://www.reuters.com/article/us-southkorea-military-analysis/buying-a-big-stick-south-koreas-military-spending-has-north-korea-worried

Smith J and Stewart P (2018) Trump surprises with pledge to end military exercises in South Korea. Reuters (12). Available at: https://www.reuters.com/article/us-northkorea-usamilitary/trump-surprises-with-pledge-to-end-military-exercises-in-south-korea-idUS

Sorokin GL (1994) Arms, alliances, and security tradeoffs in enduring rivalries. International Studies Quarterly 38: 421-446.

Thompson W and Dreyer D (2011) Handbook of International Rivalries. Washington, DC: CQ Press.

\section{Author biographies}

Matthew Di Giuseppe is an Assistant Professor at Leiden University. He studies the political economy, security, and the intersection between the two fields. He has published in a variety of journals including the British Journal of Political Science, International Studies Quarterly, Journal of Conflict Resolution, Journal of Peace Research, Foreign Policy Analysis, and Economics \& Politics.

Patrick E. Shea is an Associate Professor at the University of Houston. His research interests are International Relations, the political economy of conflict processes, and statistical inference. He has published in a variety of journals including International Studies Quarterly, Journal of Conflict Resolution, Journal of Peace Research, International Interactions, Social Science History, and Economics \& Politics. 